\title{
Production and Quality of Pill-Millipede Manure: A Microcosm Study
}

\author{
Cheviri Nair Ambarish · Kandikere Ramaiah Sridhar
}

Received: 25 April 2013/Accepted: 17 July 2013/Published online: 23 August 2013

(C) NAAS (National Academy of Agricultural Sciences) 2013

\begin{abstract}
This study deals with the production of manure by two pill-millipedes (Arthrosphaera fumosa and A. magna) that harbour in the Western Ghat forests of India, from mixed leaf litter of three plant species (Lagerstroemia microcarpa, Pongamia pinnata and Terminalia paniculata) under laboratory microcosm incubation for 4 weeks. Comparison of feed (applied as mixed leaf litter; ratio, 1:1:1 w/w/w) and manure (faecal pellets) of both millipedes revealed significantly lower total phenolics, organic carbon and $\mathrm{C} / \mathrm{N}$ ratio $(p<0.05)$ in the manure. On the other, the contents of total nitrogen and phosphorus were significantly enhanced $(p<0.05)$. Our studies further indicate the possibility of harvesting the manure, from pill-millipedes fed on mixed leaf litter, with increased contents of nitrogen and phosphorus over a short duration. Performance of both manures showed similar impact with higher biomass of root and shoot, and length of cowpea (Vigna unguiculata) and finger millet (Eleusine coracana). During the third week, cowpea showed root nodulation indicating the presence of plant growth-promoting rhizobia in the manure. Depending on the geographical and environmental conditions, suitable pill-millipedes could be employed for in situ and ex situ manure production for improving agricultural productivity.
\end{abstract}

Keywords Leaf litter $\cdot$ Pill-millipedes $\cdot$ Faecal pellets $\cdot$ Manure $\cdot$ Plant growth

\section{Introduction}

Composting is a complex phenomenon of transformation of biodegradable wastes into stable organic matter valuable for agriculture by the involvement of a variety of saprophagous fauna and microorganisms. Saprophagous fauna especially millipedes, woodlice and larvae of Diptera are known to ingest up to $20-100 \%$ of the total litter in forest floor per annum [30]. The faecal matter of saprophagous fauna is characterized by undigested plant residues, fine particulate organic matter, minerals, high water holding capacity and high surface to volume ratio [18-20, 26, 30]. The most important requirement of organic matter processing is to increase the surface area by shredding saprophagous fauna,

C. N. Ambarish · K. R. Sridhar ( $₫)$

Department of Biosciences, Mangalore University,

Mangalagangotri, Mangalore 574 199, Karnataka, India

e-mail: kandikere@gmail.com which enhances the microbial activities and in turn bioconversion. Vermicompost production using earthworms is one of the most attractive, popular and cost-effective approaches in organic waste transformation. Besides earthworms, millipedes are also useful saprophagous fauna distributed widely in temperate and tropical habitats $[11,27]$. Their body structure and feeding behaviour are responsible for mechanical fragmentation, redistribution, mineralization and release essential elements from organic matter [9, 12, 14].

The order Sphaerotheriida (pill-millipedes; class, Diplopoda) has four families encompassing about 325 species with wide distribution: (i) Sphaerotheriidae (South Africa); (ii) Procyliosomatidae (Australia and New Zealand); (iii) Arthrosphaeridae (Southern India and Madagascar) and (iv) Zephroniidae (or Sphaeropoeidae) (Seychelles, Southeast Asia and Sundalands) $[35,36]$. Among the pill-millipedes, the genus Glomeris are confined to temperate regions, Arthrosphaera are distributed in selected tropical habitats, Sphaeromimus and Zoosphaerium are known from Madagascar and 
Cynotelopus is endemic to the Western Australia [21, 27, 33, 34, 36]. Large-bodied pill-millipedes of the genus Arthrosphaera without poison glands and devoid of offensive odour roll-up into marble to tennis ball or baseball size helpful for easy handling in organic matter processing. In the Western Ghats, four species are confined to high altitude regions ( $\mathrm{Ar}$ throsphaera davisoni, A. disticta, A. fumosa and A. zebraica), two species are restricted to foothill regions (A. magna and $A$. dalyi) and the west coast regions (A. magna and Arthrosphaera sp.) are rarely colonized [2, 5, 15]. Under the laboratory conditions $\left(26-28{ }^{\circ} \mathrm{C}\right)$, on feeding mixed leaf litter in glass tanks, four Arthrosphaera species survived up to $98 \%$ during wet (June-November) and up to 75-86\% during dry (December-May) seasons. Some of them hibernated and moulted in the laboratory during summer season, a few showed mating behaviours and some laid eggs followed by emergence of juveniles in fairly cool conditions $\left(21-24{ }^{\circ} \mathrm{C}\right)$ during monsoon and post-monsoon seasons. The objectives of the present study were: (i) production of pill-millipede manure by offering mixed leaf litter in microcosm; (ii) assessment of quality of manure and (iii) evaluation of manure potential in plant production.

\section{Materials and Methods}

\section{Microcosm Setup}

Glass tanks $(30 \times 15 \mathrm{~cm})$ were used as laboratory microcosm for manure production by pill-millipedes. Fallen and partially decomposed $250 \mathrm{mg}$ leaf litter each of Lagerstroemia microcarpa, Pongamia pinnata and Terminalia paniculata were mixed and transferred to each tank. The leaf litter was allowed to wet with tap water (excess water is not desirable for millipedes' activity and the faecal pellets will not be intact leading to difficulty to separate from leaf litter). Top of the tanks was covered with wire mesh to avoid escape of animals. To each tank, four pre-weighed pill-millipedes (Arthrosphaera fumosa and A. magna collected from the Western Ghats were marked on the anal tergite for recognition) were released separately. Three replicate tanks were maintained for evaluating the manure production, composition and assessment. On every week up to 4 weeks, millipedes, leaf litter and faecal pellets were separated. Each animal was weighed (fresh weight), faecal pellets (produced by four millipedes) accumulated in each tank were spread, air-dried (48 h) and weighed. Millipedes and leftover leaf litter were transferred into the respective tanks on each week of harvest of manure.

\section{Manure Evaluation}

The air-dried manure sampled on each week was assessed for physicochemical and elemental composition. Total phenolics (Folin-Dennis assay) [25], organic carbon (Walkley and Black's rapid titration method), total nitrogen (micro-Kjeldahl method) and total phosphorus (ascorbic acid method) were determined [13]. Millipede manure 50-100 mg was extracted twice with methanol (50\%) in a water bath $\left(95^{\circ} \mathrm{C}, 10 \mathrm{~min}\right)$. The pooled extract was made up to $10 \mathrm{ml}$, an aliquot $(0.5 \mathrm{ml})$ was mixed with distilled water $(0.5 \mathrm{ml})$ and treated with $\mathrm{Na}_{2} \mathrm{CO}_{3}$ in $\mathrm{NaOH}(0.1 \mathrm{~N}$, $5 \mathrm{ml}$ ). After incubation (10 min), Folin-Ciocalteus reagent $(0.5 \mathrm{ml})$ was added and optical density was read $(725 \mathrm{~nm})$ with tannic acid as standard. Organic carbon in manure (50-150 mg) was oxidized into $\mathrm{CO}_{2}$ by $\mathrm{K}_{2} \mathrm{Cr}_{2} \mathrm{O}_{7}(1 \mathrm{~N})$. The excess $\mathrm{K}_{2} \mathrm{Cr}_{2} \mathrm{O}_{7}$ after oxidation was titrated against $\left(\mathrm{NH}_{4}\right)_{2} \mathrm{SO}_{4} \cdot \mathrm{FeSO}_{4} \cdot 6 \mathrm{H}_{2} \mathrm{O}(0.5 \mathrm{~N})$ with diphenylamine indicator. For the total nitrogen estimation, manure samples (100 mg) were digested with catalytic mixture $(1 \mathrm{~g})$ and concentrated sulphuric acid $(10 \mathrm{ml})$. The digest was diluted with distilled water (up to $100 \mathrm{ml}$ in standard flask), aliquot $(10 \mathrm{ml})$ was distilled in micro-Kjeldahl apparatus, released ammonia was absorbed into boric acid $(2 \%, 10 \mathrm{ml})$ and titrated against $\mathrm{HCl}(0.01 \mathrm{~N})$ with mixed indicator. The total phosphorus was extracted on ashing the manure samples (200-300 mg), diluted with concentrated $\mathrm{HCl}$, filtered and the absorbance was read $(880 \mathrm{~nm})$ using reagent blank as the reference. The known concentration of $\mathrm{KH}_{2} \mathrm{PO}_{4}$ served as standard for calibration. The $\mathrm{pH}$ and conductivity of manure were measured using water analyser (Systronics 371, Ahmedabad, India). The manure was digested with diacid mixture $\left(\mathrm{HNO}_{3}\right.$ and $\left.\mathrm{HClO}_{4}\right)$ to estimate minerals (calcium, sodium, potassium, magnesium, manganese, iron, copper, zinc and selenium) using atomic absorption spectrophotometry (GBC 902; Australia) [4]. Mature of three leaf litters (ratio, 1:1:1) offered on the first day was also assessed for the chemical composition as detailed above.

\section{Manure Performance}

The Neubauer technique was employed to assess the quality of pill-millipede manure [32]. This technique allows estimating the uptake of nutrients by plants grown in processed sand amended with known quantity of test manure. Besides, it is also useful in determining the microand macro-nutrients necessary for plant growth. The sandmanure mixture allows roots to penetrate easily and rapid utilization of nutrients. River sand samples were collected, wetted, rinsed in running tap water and sieved $(2 \mathrm{~mm}$ sieve) to eliminate pebbles and coarse organic matter [3]. Sieved sand was further washed in boiling distilled water to eliminate clay particles, treated with hot acid-water $(10 \mathrm{ml}$ concentrated $\mathrm{H}_{2} \mathrm{SO}_{4}$ in $1000 \mathrm{ml}$ distilled water) (30 min) to remove the remaining organic matter. On cooling, the sand was repeatedly washed in cold distilled water to remove the acid traces followed by air-drying. Transparent polythene 
bags $(15 \times 10 \mathrm{~cm})$ devoid of drain holes were used to grow plants. Processed dry sand $(400 \mathrm{~g})$ was mixed with millipede manure (100 g; mixture of $25 \mathrm{~g}$ from each week) and was transferred per bag and watered daily. Three replicate bags were maintained per treatment.

For evaluation of manure efficiency, one each of dicot (cowpea, Vigna unguiculata) and monocot (finger millet, Eleusine coracana) were chosen. The seeds were soaked in water up to $6 \mathrm{~h}$, water was drained and seeds were allowed to germinate overnight. Germinated cowpea (4 seeds per bag) and finger millet (25 seeds per bag) were sown at $1-\mathrm{cm}$ depth on sand bed in each bag separately. The bags were incubated $\left(24 \pm 2{ }^{\circ} \mathrm{C}\right)$ and watered regularly $(5 \mathrm{ml}$ per bag twice a day) up to 4 weeks. At the end of each week, plants were uprooted, length of shoot and the longest root were measured (average per survived plants in three replicates). The dry mass of shoot and root of survived plants in each bag was determined gravimetrically (drying at $80{ }^{\circ} \mathrm{C}, 24 \mathrm{~h}$ ). The processed sand without addition of manure served as control. Root nodules formed in cowpea treated with pill-millipede manure during the third week were enumerated.
Data Analysis

The impact of manure on increase of biomass as well as length of shoot and root of plant species was determined by deducting the control value. To follow the changes in physicochemical and elemental composition between food (mixed leaf litter) and manure produced from 1 to 4 weeks, one-way ANOVA was employed (SigmaPlot 11; Systat Software Inc. USA). The differences in biomass and length (shoot and root) of plant species grown in two manures for 4 weeks duration were assessed by $t$ test [29].

\section{Results and Discussion}

\section{Manure Composition}

The pill-millipedes are known to ingest partially decomposed (conditioned) leaf litter, transform into mineral-rich manure and enrich the soil with organic matter as well as associated microbes $[5,14]$. In the present study, partially decomposed specific mixed leaf litter combination was offered to
Fig. 1 Dry weight of manure produced by four pill-millipedes $(n=3 \pm \mathrm{SD}$ ) (week 1 vs $2-4$, $p<0.05)$; wet weight of each millipede $(n=12 \pm \mathrm{SD})(A$. magna: week 1 vs 3-4, $p<0.05$; one-way ANOVA); changes in total phenolics, organic carbon, total nitrogen contents and $\mathrm{C} / \mathrm{N}$ ratio of leaf litter ( 0 week) and in manure (1-4 weeks) (all parameters in leaf litter vs manure of millipedes week $1-4, p<0.05$; one-way ANOVA)
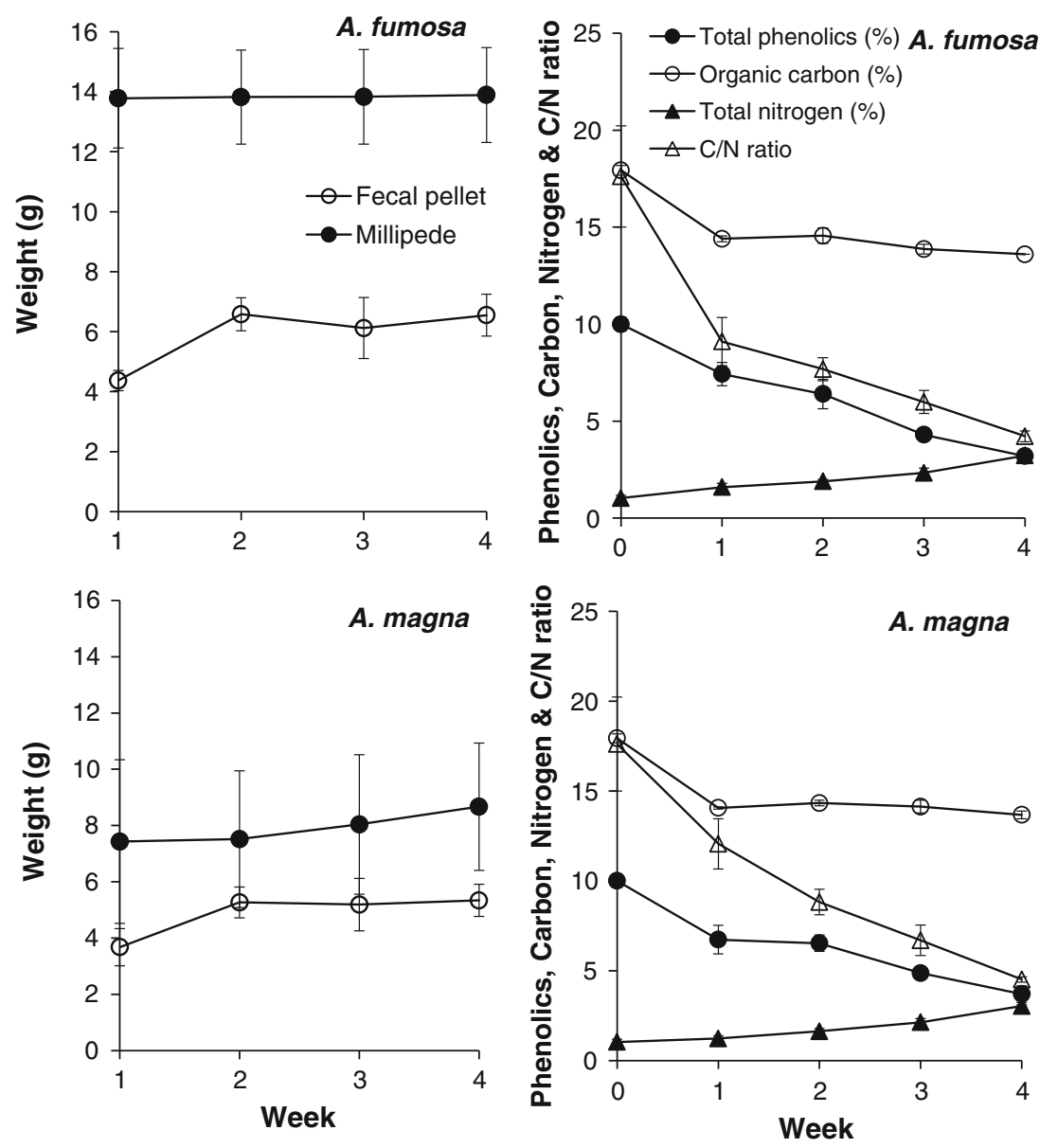
millipedes to produce manure. Figure 1 represents the comparison of weight of manure produced (four millipedes; $n=3)$ and weight of millipedes $(n=12)$ employed for leaf litter feeding for a period 1-4 weeks. Weight of manure of the first week versus 2-4 weeks in both millipedes showed a significant increase $(p<0.05)$. Figure 1 also shows total phenolics, organic carbon, total nitrogen contents and $\mathrm{C} / \mathrm{N}$ ratio between mixed leaf litter (control) and manure during 1-4 weeks. The total phenolics, organic carbon contents and $\mathrm{C} / \mathrm{N}$ ratio were significantly decreased between feed (mixed leaf litter) and manure $(p<0.05)$, while the total nitrogen content was significantly enhanced $(p<0.05)$. Table 1 shows changes in $\mathrm{pH}$, conductivity and minerals in mixed leaf litter and millipede manure during 1-4 weeks. The $\mathrm{pH}$ became slightly acidic during 1-3 weeks (A. fumosa, $p<0.05$ ), while in the fourth week it was almost similar to that of mixed leaf litter $(p>0.05)$ indicating restoration of $\mathrm{pH}$ in manure in the fourth week. The conductivity was significantly increased in manure of A. fumosa ( $p<0.001)$, but it was reverse in the manure produced by A. magna $(p<0.001)$. The phosphorus content of manure attained significantly highest level during the second week (A. fumosa, $p<0.01$ ) or the third week (A. magna, $p<0.001$ ). The zinc content was significantly decreased in manure $(p<0.001)$ in all the weeks except for the fourth week in A. magna, while no major changes occurred in rest of the minerals between mixed leaf litter and manure. However, calcium, sodium, potassium and magnesium contents differed drastically between the manures indicating difference in processing of mixed leaf litter by the two pill-millipedes.

The overall dynamics of pattern of leaf litter processing, manure production and nutrient contents of pill-millipede manures in the present study corroborates with the earlier greenhouse and laboratory trials [5-7, 14, 28]. Organic matter in the manures of pill-millipedes fed with Acacia, banana, cashew and coconut leaf litter separately by amendment of soil was higher compared to those fed only soil (70.1-75.8 vs $9.3 \%$ ) [6]. Thus, mixed leaf litter

Table 1 Changes in physicochemical features of manure of pill-millipedes (Pm) A. fumosa (Af) and A. magna (Am) on mixed leaf litter diet in $\operatorname{microcosm}(n=3$, mean $\pm \mathrm{SD})$

\begin{tabular}{|c|c|c|c|c|c|c|}
\hline & \multirow[t]{2}{*}{ Leaf litter } & \multirow[t]{2}{*}{$\mathrm{Pm}$} & \multicolumn{4}{|l|}{ Manure } \\
\hline & & & Week 1 & Week 2 & Week 3 & Week 4 \\
\hline \multirow[t]{2}{*}{$\mathrm{pH}$} & \multirow[t]{2}{*}{$6.94 \pm 0.04^{\mathrm{a}}$} & Af & $6.22 \pm 0.21^{\mathrm{b} * * *}$ & $6.47 \pm 0.18^{\mathrm{b}_{* *}}$ & $6.75 \pm 0.09^{\mathrm{b} *}$ & $6.90 \pm 0.07^{\mathrm{a}}$ \\
\hline & & $\mathrm{Am}$ & $6.59 \pm 0.03^{\mathrm{b} *}$ & $6.65 \pm 0.04^{\mathrm{a}}$ & $6.80 \pm 0.09^{\mathrm{a}}$ & $6.91 \pm 0.04^{\mathrm{a}}$ \\
\hline \multirow[t]{2}{*}{ Conductivity $(\mu \mathrm{S} / \mathrm{cm})$} & \multirow[t]{2}{*}{$144.33 \pm 2.08^{\mathrm{a}}$} & Af & $177 \pm 3.61^{\mathrm{b} * * *}$ & $186 \pm 3.61^{\mathrm{b} * * *}$ & $196.3 \pm 1.53^{\mathrm{b} * * *}$ & $206.3 \pm 3.51^{\mathrm{b}_{* * *}}$ \\
\hline & & $\mathrm{Am}$ & $90.8 \pm 0.21^{\mathrm{b} * * *}$ & $95.23 \pm 0.16^{\mathrm{b} * * *}$ & $104.67 \pm 1.65^{\mathrm{b} * * *}$ & $112 \pm 1.14^{\mathrm{b} * * *}$ \\
\hline \multirow[t]{2}{*}{ Phosphorous (\%) } & \multirow[t]{2}{*}{$0.23 \pm 0.02^{\mathrm{a}}$} & Af & $0.23 \pm 0.04^{\mathrm{a}}$ & $0.37 \pm 0.02^{\mathrm{b} * *}$ & $0.27 \pm 0.05^{\mathrm{b} * * *}$ & $0.12 \pm 0.03^{\mathrm{b} * * *}$ \\
\hline & & $\mathrm{Am}$ & $0.18 \pm 0.03^{\mathrm{b}_{* *}}$ & $0.24 \pm 0.01^{\mathrm{b} *}$ & $0.28 \pm 0.02^{\mathrm{b} * * *}$ & $0.09 \pm 0.01^{\mathrm{b} * * *}$ \\
\hline \multirow[t]{2}{*}{ Calcium (\%) } & \multirow[t]{2}{*}{$0.304 \pm 0.02^{\mathrm{a}}$} & Af & $0.10 \pm 0.02^{\mathrm{b} *}$ & $0.19 \pm 0.04^{\mathrm{a}}$ & $0.18 \pm 0.02^{\mathrm{a}}$ & $0.164 \pm 0.02^{\mathrm{a}}$ \\
\hline & & $\mathrm{Am}$ & $0.14 \pm 0.02^{\mathrm{a}}$ & $0.20 \pm 0.03^{\mathrm{a}}$ & $0.14 \pm 0.03^{\mathrm{a}}$ & $0.28 \pm 0.019^{\mathrm{a}}$ \\
\hline \multirow[t]{2}{*}{ Sodium (\%) } & \multirow[t]{2}{*}{$0.068 \pm 0.010^{\mathrm{a}}$} & Af & $0.04 \pm 0.0045^{\mathrm{b} *}$ & $0.11 \pm 0.012^{\mathrm{b} * *}$ & $0.08 \pm 0.021^{\mathrm{a}}$ & $0.05 \pm 0.0019^{*}$ \\
\hline & & Am & $0.06 \pm 0.01^{\mathrm{a}}$ & $0.06 \pm 0.01^{\mathrm{a}}$ & $0.09 \pm 0.003^{\mathrm{a}}$ & $0.07 \pm 0.01^{\mathrm{a}}$ \\
\hline \multirow[t]{2}{*}{ Potassium (\%) } & \multirow[t]{2}{*}{$0.6875 \pm 0.81^{\mathrm{a}}$} & Af & $0.13 \pm 0.02^{\mathrm{a}}$ & $0.46 \pm 0.05^{\mathrm{a}}$ & $0.22 \pm 0.02^{\mathrm{a}}$ & $0.19 \pm 0.03^{\mathrm{a}}$ \\
\hline & & $\mathrm{Am}$ & $0.17 \pm 0.04^{\mathrm{a}}$ & $0.16 \pm 0.035^{\mathrm{a}}$ & $0.13 \pm 0.02^{\mathrm{a}}$ & $0.20 \pm 0.03^{\mathrm{a}}$ \\
\hline \multirow[t]{2}{*}{ Magnesium (\%) } & \multirow[t]{2}{*}{$0.460 \pm 0.19^{\mathrm{a}}$} & Af & $0.27 \pm 0.02^{\mathrm{a}}$ & $0.60 \pm 0.08^{\mathrm{a}}$ & $0.28 \pm 0.09^{\mathrm{a}}$ & $0.13 \pm 0.03^{\mathrm{a}}$ \\
\hline & & $\mathrm{Am}$ & $0.50 \pm 0.03^{\mathrm{a}}$ & $0.41 \pm 0.03^{\mathrm{a}}$ & $0.47 \pm 0.17^{\mathrm{a}}$ & $0.47 \pm 0.19^{\mathrm{a}}$ \\
\hline \multirow[t]{2}{*}{ Manganese (\%) } & \multirow[t]{2}{*}{$0.0367 \pm 0.0102^{\mathrm{a}}$} & Af & $0.01 \pm 0.001^{\mathrm{b} * *}$ & $0.02 \pm 0.0104^{\mathrm{a}}$ & $0.03 \pm 0.003^{\mathrm{a}}$ & $0.02 \pm 0.002^{\mathrm{b} * *}$ \\
\hline & & $\mathrm{Am}$ & $0.02 \pm 0.003^{\mathrm{b} * *}$ & $0.02 \pm 0.004^{\mathrm{a}}$ & $0.03 \pm 0.004^{\mathrm{a}}$ & $0.03 \pm 0.008^{\mathrm{a}}$ \\
\hline \multirow[t]{2}{*}{ Iron $(\%)$} & \multirow[t]{2}{*}{$0.045 \pm 0.0190^{\mathrm{a}}$} & Af & $0.01 \pm 0.004^{\mathrm{a}}$ & $0.02 \pm 0.001^{\mathrm{a}}$ & $0.02 \pm 0.003^{\mathrm{a}}$ & $0.05 \pm 0.07^{\mathrm{a}}$ \\
\hline & & $\mathrm{Am}$ & $0.01 \pm 0.002^{\mathrm{a}}$ & $0.02 \pm 0.001^{\mathrm{a}}$ & $0.01 \pm 0.001^{\mathrm{a}}$ & $0.04 \pm 0.02^{\mathrm{a}}$ \\
\hline \multirow[t]{2}{*}{ Copper (\%) } & \multirow[t]{2}{*}{$0.003 \pm 0.0004^{\mathrm{a}}$} & Af & $0.002 \pm 0.001^{\mathrm{a}}$ & $0.005 \pm 0.002^{\mathrm{a}}$ & $0.005 \pm 0.004^{\mathrm{a}}$ & $0.004 \pm 0.001^{\mathrm{a}}$ \\
\hline & & $\mathrm{Am}$ & $0.005 \pm 0.002^{\mathrm{a}}$ & $0.003 \pm 0.001^{\mathrm{a}}$ & $0.006 \pm 0.003^{\mathrm{a}}$ & $0.003 \pm 0.0004^{\mathrm{a}}$ \\
\hline \multirow[t]{2}{*}{ Zinc $(\%)$} & \multirow[t]{2}{*}{$0.034 \pm 0.0047^{\mathrm{a}}$} & Af & $0.01 \pm 0.001^{\mathrm{b} * * *}$ & $0.02 \pm 0.004^{\mathrm{b} * * *}$ & $0.01 \pm 0.003^{\mathrm{b} * * *}$ & $0.01 \pm 0.001^{\mathrm{b} * * *}$ \\
\hline & & $\mathrm{Am}$ & $0.01 \pm 0.001^{\mathrm{b} * * *}$ & $0.02 \pm 0.003^{\mathrm{b} * * *}$ & $0.02 \pm 0.002^{\mathrm{b} * * *}$ & $0.03 \pm 0.004^{\mathrm{a}}$ \\
\hline \multirow[t]{2}{*}{ Selenium (\%) } & \multirow[t]{2}{*}{$0.012 \pm 0.0015^{\mathrm{a}}$} & Af & $0.01 \pm 0.001^{\mathrm{a}}$ & $0.01 \pm 0.001^{\mathrm{b} * *}$ & $0.01 \pm 0.001^{\mathrm{a}}$ & $0.01 \pm 0.001^{\mathrm{a}}$ \\
\hline & & $\mathrm{Am}$ & $0.01 \pm 0.001^{\mathrm{a}}$ & $0.01 \pm 0.001^{\mathrm{a}}$ & $0.01 \pm 0.001^{\mathrm{a}}$ & $0.01 \pm 0.002^{\mathrm{a}}$ \\
\hline
\end{tabular}

Figures across the columns between control and experimental samples (1-4 weeks) with different alphabets are significantly different (one-way ANOVA)

$* p<0.05 ; * * p<0.01 ; * * * p<0.001$ 
feeding by millipedes enriches the soil with high quantity of organic matter and thereby increases the microbial activity. Kadamannaya and Sridhar [14] also demonstrated the increase of nitrogen and phosphorus contents and decrease of total phenolics and $\mathrm{C} / \mathrm{N}$ ratio in pill-millipede manure on feeding plantation residues under laboratory conditions. Increase in the nitrogen, phosphorus and potassium, while decrease in the $\mathrm{C} / \mathrm{N}$ ratio in manures of pill-millipedes fed with mixed leaf litter diet was demonstrated by Ashwini and Sridhar [7]. However, in the present study, even though nitrogen and phosphorus contents increased in manures, the potassium content decreased possibly due to fastidious absorption by millipedes. This finding corroborates with the observation by McBrayer [22] that significant high assimilation of potassium by millipedes was during coprophagy. The present study demonstrated that it is possible to harvest the manure from pill-millipedes by offering mixed leaf litter within a short period with appreciable quantity of nitrogen (4 weeks) and phosphorus ( 2 or 3 weeks). In one of the replicates during the third week of composting, eggs of earthworms (likely present in the decomposing leaf litter offered) hatched out and a few active juveniles were seen indicating the possibilities of employing combination of millipedes and earthworms for manure production.
Manure Quality

Figure 2 presents increased biomass and length of shoot and root of cowpea and finger millet nourished by manures of two millipedes (A. fumosa and A. magna). The shoot and root biomass of cowpea showed steady increase from week 1 to 4 grown in both manures, while it was less pronounced in finger millet. Steady increase was also evident in the length of shoot and root in both the plants. There was no significant difference in biomass and length of plant species after 4 weeks of growth in both the manures except for root biomass of cowpea $(p<0.05)$. The overall performance of both manures showed similar effect in building shoot and root biomass as well as length of shoot and root in cowpea and finger millet denoting their suitability for amending with soil for plant production. Experiments on the dry mass yield in black gram (Phaseolus mungo) and finger millet (E. coracana) showed that pill-millipede compost produced using plantation residues compensates the deficiency of nutrients in farmyard manure [6]. Organically managed plantations are ideal for colonization of pill-millipedes and the most colonized region in plantations would be the basins of plantations (e.g. coconut, areca and cocoa) receiving mixed organic wastes and serving in in situ compost production. Based on the pattern
Fig. 2 Performance of pillmillipede manure in increase of biomass and length of shoot and root of cowpea $(\mathrm{Cp})$ and finger millet $(\mathrm{Fm})(n=3 \pm \mathrm{SD})$ (root biomass of cowpea grown in manures of $A$. fumosa vs $A$. magna in the fourth week significantly differed, $p<0.05$; $t$ test)
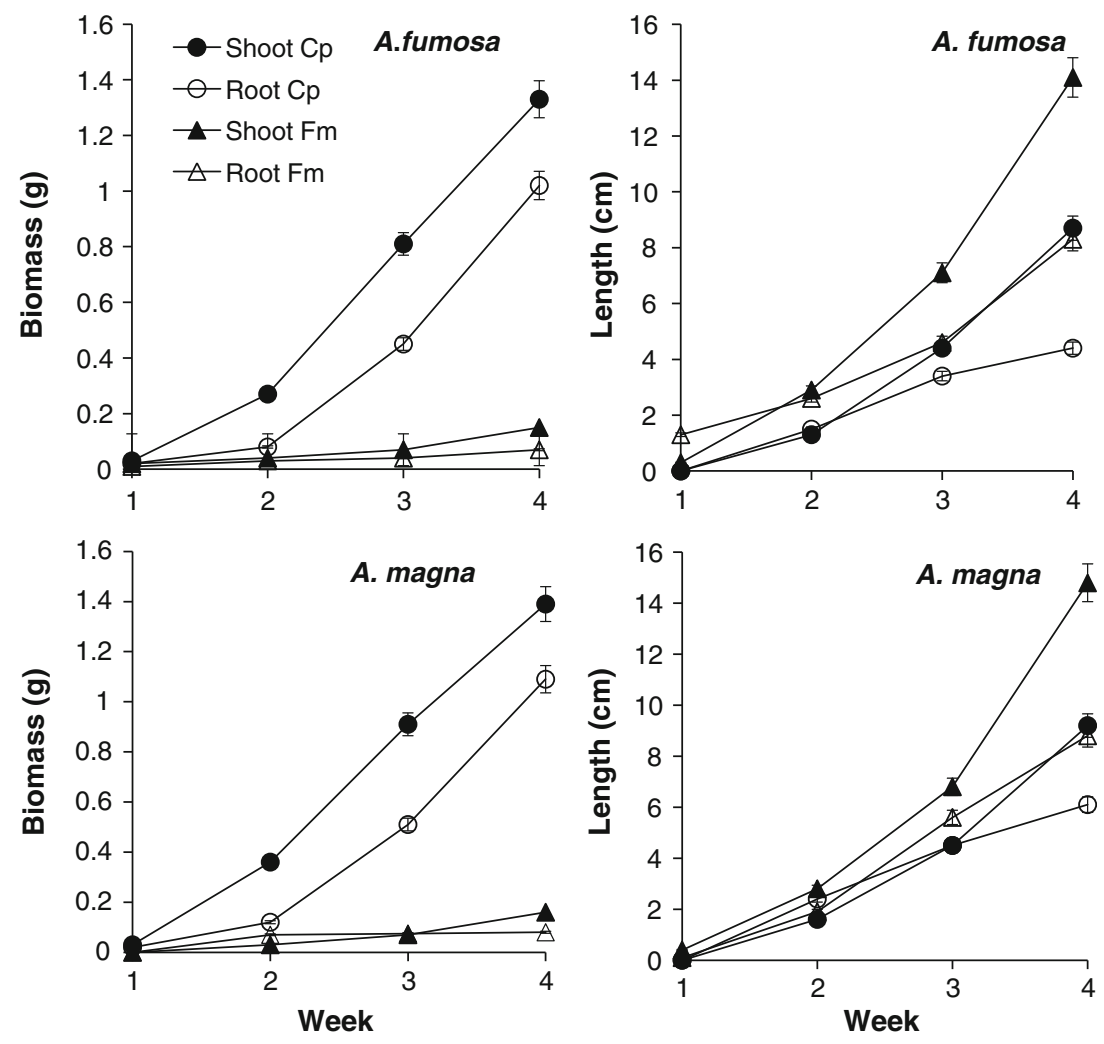
of distribution in the Western Ghats, some pill-millipedes are suitable for manure production in high-elevated regions (800 $\mathrm{m}$ and above) (e.g. A. davisoni, A. disticta and A. zebraica), while some of them are suitable for mid-elevated regions (250-500 m) (e.g. A. dalyi and A. magna).

It is presumed that favourable changes in the quality of manure were brought by the action of microbes in leaf litter and in the millipede gut. The structural components of plant litter like cellulose and hemicellulose degradation takes place in millipede gut through the microbes [31]. Degradation of organic matter and recycling of detritus are favoured by the enhancement of gut microflora of millipedes $[1,16,17]$. Cellulose was preferentially decomposed by the microorganisms in faeces and suggests the occurrence of cellulolytic microorganisms in millipede gut [8]. Compost produced by the pill-millipedes showed higher biomass as well as fruit yield in capsicum (Capsicum anпиит) compared to the conventional manure and vermicompost [24]. Similar results on millipede manure were also reported by Prabhas et al. [23]. Besides, the population of plant growth-promoting microbes might be enhanced in the manures of pill-millipedes. For instance, cowpea plants showed root nodules during the third week of growth in both manures (A. fumosa, $19.3 \pm 3.5$ /plant; A. magna, $21 \pm 1 /$ plant). Similarly, the increase in phosphate content in manures may be attributed to the activity of phosphatesolubilising microbes in leaf litter and millipede gut.

\section{Conclusions}

Our study demonstrated that it is possible to maintain the pillmillipedes in microcosms cost-effectively under normal conditions for production of manure for sustainable agriculture. Partially decomposed mixed leaf litter serves as good feedstock for production of millipede manure. Similarly, the urban organic wastes are also suitable for bioconversion into manure by millipedes and cut down the extent of landfill [28]. The pill-millipedes serve as better candidates in manure production as their lifespan is up to 11 years [10]. Evaluation of quality of millipede manure by specific combination and proportion of the mixed leaf litter facilitates commercial production. Future studies should evaluate the occurrence of plant growth-promoting bacteria (e.g. rhizobia) and fungi (e.g. mycorrhizas) in millipede manures. Further insights are also necessary on the improvement of quality of millipede manure by assessment of natural and inoculated microbial bioprotectants (e.g. Trichoderma).

Acknowledgments The authors are grateful to Mangalore University for permission to carry out studies on pill-millipedes in the Department of Biosciences. We are thankful to the authorities of Mangalore Chemical Fertilizers, Panambur, Mangalore for mineral assessment of mixed leaf litter and pill-millipede compost. CNA acknowledges the award of Inspire Fellowship, Department of Science and Technology, New Delhi, Government of India (DST/ INSPIRE Fellowship/2011/(294): Award \# IF110540). We appreciate the editor and reviewers who improved the early version of this manuscript.

\section{References}

1. Alagesan P, Ashok KB, Muthukrishanan J, Gunasekaran P (2003) Isolation and characterization of gut bacteria of millipede, $\mathrm{Xe}$ nobolus carnifex (Fabricius). Indian J Microbiol 43:111-113

2. Ambarish CN, Sridhar KR (2013) Observation on pill-millipedes of the Western Ghats (India). J Agric Technol 9:61-79

3. Anand JA, Wilson MDP, Kale RD (1995) Effect of vermiwash on seed germination and seedling growth. J Soil Biol Ecol 15:90-95

4. AOAC (2005) Official methods of analysis of the association of official analytical chemists, 5th edn. Official Analytical Chemists Inc, Arlington, VA

5. Ashwini KM, Sridhar KR (2005) Leaf litter preference and conversion by a saprophagous tropical pill millipede, Arthrosphaera magna Attems. Pedobiologia 49:307-316

6. Ashwini KM, Sridhar KR (2006) Feeding response of an endemic pill millipede Arthrosphaera magna Attems to plantation litter. J Plant Crops 34:58-62

7. Ashwini KM, Sridhar KR (2006) Breakdown of plantation residues by pill millipedes (Arthrosphaera magna) and assessment of compost quality. Curr Sci 90:954-959

8. Coûteaux M-M, Aloui A, Kurz-Besson C (2002) Pinus halepensis litter decomposition in laboratory microcosms as influenced by temperature and a millipede, Glomeris marginata. Appl Soil Ecol 20:85-96

9. Dangerfield JM, Milner AE (1996) Millipede faecal pellet production in selected natural and managed habitats of Southern Africa implications for litter dynamics. Biotropica 28:113-120

10. Dangerfield JM, Telford AE (1991) Seasonal activity pattern of julid millipedes in Zimbabwe. J Trop Ecol 7:281-285

11. Golovatch SI, Kime RD (2009) Millipede (Diplopoda) distributions: a review. Soil Org 81:565-597

12. Hopkin SP, Read HJ (1992) The biology of millipedes. Oxford University Press, Oxford

13. Jackson ML (1973) Soil chemical analysis. Prentice Hall International, Englewood Cliffs

14. Kadamannaya BS, Sridhar KR (2009) Leaf litter ingestion and assimilation by two endemic pill millipedes (Arthrosphaera) of the Western Ghats, India. Biol Fertil Soils 45:761-768

15. Kadamannaya BS, Sridhar KR, Sreepada KS (2010) Assemblage and distribution of pill millipedes and earthworms in relation to soil edaphic features in the Western Ghats and the west coast of India. Front Agric China 4:243-250

16. Kaneko N (1999) Effect of millipede Parafontaria tonominea Attems (Diplopoda: Xystodesmidae) adults on soil biological activities: a microcosm experiment. Ecol Res 14:271-279

17. Karthigeyan M, Alagesan P (2011) Millipede composting: a novel method for organic waste recycling. Recent Res Sci Technol 3:62-67

18. Kheirallah AM (1990) Fragmentation of leaf litter by a natural population of the millipede Julus scandinavius (Latzel 1884). Biol Fertil Soils 10:202-206

19. Kurzatkowski D, Martius C, Höfer H, Garcia M, Förster B, Beck L, Vlek P (2004) Litter decomposition, microbial biomass and activity of soil organisms in three agroforestry sites in central Amazonia. Nutr Cycl Agroecosyst 69:257-267

20. Lavelle P, Spain AV (2001) Soil ecology. Kluwer, Amsterdam 
21. Main BY, Harvey MS, Waldock JM (2002) The distribution of the Western Australian pill millipede, Cynotelopus notabilis Jeekel (Sphaerotheriidae). Rec West Aust Mus 20:383-385

22. McBrayer JF (1973) Exploitation of deciduous leaf litter by Apheloria montana (Diplopoda: Eurydesmidae). Pedobiologia 13:90-98

23. Prabhas CT, Apurva P, Shailendra KS (2011) Comparative study of characteristics of biocompost produced by millipedes and earthworms. Adv Appl Sci Res 2:94-98

24. Ramanathan B, Alagesan P (2012) Evaluation of millicompost versus vermicompost. Curr Sci 103:140-143

25. Rosset J, Bärlocher F, Oertli JJ (1982) Decomposition of conifer needles and deciduous leaves in two Black Forest and two Swiss Jura streams. Int Rev Ges Hydrobiol 67:695-711

26. Seeber J, Seeber GUH, Langel R, Scheu S, Meyer E (2008) The effect of macro-invertebrates and plant litter of different quality on the release of $\mathrm{N}$ from litter to plant on alpine pastureland. Biol Fertil Soils 44:783-790

27. Sierwald P, Bond JE (2007) Current status of the Myriapod class Diplopoda (millipedes): taxonomic diversity and phylogeny. Ann Rev Entomol 52:401-420

28. Sridhar KR, Ambarish CN (2013) Pill-millipede compost: a viable alternative to utilize urban organic solid wastes. Curr Sci 104:1543-1547
29. StatSoft (2008) Statistica version 8. StatSoft Inc, Oklahoma

30. Tajovský K, Šantrůčková H, Hánĕl L, Balík LA (1992) Decomposition of faecal pellets of the millipede Glomeris hexasticha (Diplopoda) in forest soil. Pedobiologia 36:146-158

31. Taylor EC, Crawford CS (1982) Microbial gut symbionts and desert detritivores. Sci Rev Arid Zone Res 1:37-52

32. Tisdale SL, Nelson WL (1976) Soil fertility and fertilizers. MacMillan, New York

33. Wesener T, Sierwald P (2005) The giant pill-millipedes of Madagaskar. Proc Calif Acad Sci 56:557-599

34. Wesener T, Sierwald P (2005) New giant pill-millipede species from the littoral forest of Madagascar (Diplopada, Sphaerotheriida, Zoosphaerium). Zootaxa 1097:1-60

35. Wesener T, van den Spiegel D (2009) A first phylogenetic analysis of giant pill-millipedes (Diplopoda: Sphaerotheriida), a new model Gondwanan taxon, with special emphasis on island gigantism. Cladistics 25:1-29

36. Wesener T, Raupach MJ, Sierwald P (2010) The origins of the giant pill-millipedes from Madagascar (Diplopoda: Sphaerotheriida: Arthrosphaeridae). Mol Phylogeny Evol 57:1184-1193 